\title{
Decolonising International Relations and Its Theory: A Critical Conceptual Meditation
}

\author{
Siphamandla Zondi*
}

Department of Political Sciences, University of Pretoria, Pretoria, South Africa

*CONTACT: Siphamandla Zondi. Email: siphamandla.zondi@up.ac.za

\begin{abstract}
One of the main implications of the push for transition from the monoculture of Eurocentric scientific knowledge towards the ecology of knowledge is to force us to pose the question: what does a decolonial turn in International Relations (IR) entail? This article grapples with this question in light of growing demands for a decolonial turn in knowledge and power. The aim is to meditate on this question with a view to open up new avenues for a structured conversation on decolonising IR and its theory. This imperative to decolonise is linked to the question of epistemic justice with implications for the epistemological structure underpinning $I R$, methodological frameworks for the study of $I R$, theoretical outlines and the teaching of the discipline. Epistemic justice is a necessity alongside historical justice for those on the margins of a world system constructed with the help of imperialism, systematic enslavement and colonialism. This article discusses the question of the decolonial turn in IR in the hope of stimulating debates on the views of the margins regarding the present state and the future of this area of knowledge, and thus move us closer to an ecology of knowledge and power.
\end{abstract}

Starting from the assumption that cultural diversity and epistemological diversity are reciprocally embedded, [we] ... show that the reinvention of social emancipation is premised upon replacing the 'monoculture of scientific knowledge' by an 'ecology of knowledges'. The ecology of knowledges is ... granting 'equality of opportunities to the different kinds of knowledge engaged in ever broader epistemological disputes aimed both at maximizing their respective contributions to build a more democratic and just society and at decolonizing knowledge and power. (Santos et al. undated, p. xx)

\section{Introduction}

The quote above place at the centre of on-going debates about transitions and changes in knowledge and power the idea of epistemological diversity with a view to grant equality of opportunities to be heard and use to the different knowledges for engaging in broad epistemological debates aimed at building more democratic and just societies. This entails the need for decolonising knowledge and power. The subject of decolonisation of social and natural sciences is not new, having been a part of southern discourses of knowledge and power for decades now (Ake 1979; Wa Thiong'o 1986; Chabal 2012). It may be that the mainstreams of knowledge have only recently noticed this demand for de-imperialisation 
and decolonisation, but it is as old as the demand for decolonisation of politics, economy and global culture (Wa Thiong'o 1986; Blaut 1993). The subject lately is increasingly being connected to broader struggles for the decolonisation of economy, space, memory and politics generally as evident in the uprisings of university students and workers in South Africa (Venter 2015; Naicker 2016) and elsewhere. In recent times, the struggle for decolonised free education has shifted to the streets, television screens, social media and print media, often establishing linkages with other social struggles especially among the poor and radical forces opposed to neoliberalism and its effects on human lives.

This has in turn led to renewed academic discourses on the meanings of decolonisation, Africanisation, diversification and transformation of modern knowledge and its systems. Looking beyond narrow battles over definitions and whether the four concepts are fundamentally different calls, this article argues that taken together the demands being made entail a call for something much more fundamental than lowering or cancelling university fees, removing statues of colonial figures, mere reforms to curricula, renaming institutions and adjusting university procedures. They amount to a call for a fundamental rethinking and redoing of how knowledge is produced, taught and disseminated, processes that the university is central to. It is a demand for the decommissioning of the complex array of structures that shape through the university identity, knowledge and power. Following the positivist, and post-positivist turns, this is a call for something disruptive being more fundamental shifts we collectively call a decolonial turn in the knowledge environment and by implication in the modern state and the global system in which it is nested. Therefore, the students and poor workers have made demands that call into question the taken-for-granted power structures in the knowledge production and transmission environment and society as whole.

This has implications for the entire world system, the nation state and modern knowledge just like struggles being waged by students in other parts of the world including the UK, as the campaigns to decolonise knowledge reached Oxford University. In places like Chile, student uprisings forced to acknowledge and discussed fundamental fault lines in the Chilean education system and society in general (Williams 2015). Their rallying cry 'end profit making in education, nobody owns our dreams' put the spotlight on the very foundations of modern Chile, its position in the world system and the linkages between knowledge, neoliberal economics and injustice in society. The same is said about the efficacy of student struggles in Brazil between 1962 and 1990s that evolved into struggles for the transformation of the state and economy, thus contributing to the democratic transitions in the 1990s (Filho and Collins 1998). These student struggles shaped the turn of academic debates in the region, giving impetus to among others the idea of a decolonial turn expressed in terms of second decolonisation, epistemic disobedience, shifting the geography of reason, and so forth (Mignolo 2009; MaldonadoTorres 2011). It is because it is students who can best tell us if the knowledge we produce and teach in disciplines like International Relations (IR) are just and useful or not.

The South African student-led struggles for decolonisation of university education have the potential to have a similar impact on broad social struggles as well as on. There is evidence to suggest that the students' struggles in South Africa since 2015 have thrust upon the table of academics new fundamental questions to pose, debate, explain and seek to resolve. These relate connections between social justice and epistemic justice as well as intellectual efforts for epistemic decolonisation. Judging by the number of papers, 
seminars, conferences and publications that have emerged since 2015, there is an academic discourse that has invariably emerged to grapple with this, a testament of the efficacy of the social media-driven students struggles under the banner of \#FeesMustFall, \#RhodesMustFall and \#FreeDecolonizedEducation movements.

Time has therefore come for structured conversations within and across disciplines about the meanings and implications of the struggles for decolonised free education. Inevitably, part of this discussion must be in the form of a candid diagnosis of coloniality and Eurocentrism within disciplines, unmasking how these fundamental maladies that bedeviled our disciplines are implicated in the epistemic injustice that students say they experience. They must challenge us to see the problem we have been oblivious to for a long while. We who work in political sciences, diplomatic history, world history, IR and foreign policy analysis also need to reflect on the implications of our areas of study in coloniality of knowledge, in particular, the monoculture of Eurocentric scientific knowledge and the possibilities for a decolonial epistemic disobedience in our subject areas.

This article seeks to contribute to these discussions by offering meditations on the idea of, and an aspiration for, a decolonial turn in the study field of IR, especially in respect of IR theory, and where we could start to discuss this. The aim is not to provide a comprehensive and near-complete discussion of this subject, but it is to suggest a broad frame of the debate as a point of entry to discussions about how we might shift the geography of reason in IR from a Eurocentric monologue towards a pluriversal multilogue of epistemologies. The article suggests that we must first attempt to unmask the coloniality of IR as a discipline and as a practice, identifying what specifically and fundamentally is colonial about them. Secondly, we must clarify the implications for the decolonisation of the discipline that also enables its diversification and Africanisation in fundamental ways.

\section{On the conundrum of methodology}

In navigating towards a decolonial turn, we must detox method and methodology because we have known for sometime that they are contaminated with the ideological imports of epistemic imperialism. According to Ake $(1979,125)$, this is evident in that the mainstream methodological traditions are founded on the negation of alternative ways of understanding reality assumed to be inferior, unscientific, deviant, mythological and so forth. For this reason, decolonial meditations as a methodological option risk being disqualified, discredited and liquidated on the basis that it does not follow the dictates of Cartesian rationality and imperial reason (Sithole 2016a, 218 ). Imperial reason as a dominant epistemic lens of mainstream science is in fact found and sustained by methods and methodologies (Mignolo 2011, 56). This is because, as has been shown, methods and methodology are 'epistemic and social constructs whose intellectual, institutional, and ideological configurations are mediated and mapped by the unyielding demands of historical geography' (Zeleza 2006, 1). For this reason, method excludes, disconnects and silences. The options open should not be just on choosing a suitable method, but also questioning, rebelling against, disrupting and challenging method as understood in the mainstream. Methods are not holy cows therefore; neither are they automatically ethical routes to finding or processing pure knowledge. But they are constructed in situations that are marked by power relations, ideological agendas, class motivations, patriarchal considerations, imperial designs and other ethical challenges. 
Critical to the decolonial turn is to be open to taking a methodological position that Gordon $(2010,200)$ calls the paradox of method against method, one that permits not just rethinking methods but also unthinking them. It is about finding ways of understanding hidden and complex phenomena that dominant methodologies tend to conceal, hide or sanitise, as Sithole $(2016 a, 219)$ puts it. Decolonial meditations necessary for the decolonial turn imply disobedience against the mainstream's fixation with conventions that hide more than reveal, that complicate rather than simplify, deceive rather than explain, and that create formulae rather than ways of liberating our ability to understand phenomena deeply and broadly. The demands of the decolonial turn pose the question whether we may not exercise our methodological options on the basis that 'the positionality of the unthought can only be imagined through its affective dimension by those who are at the receiving end of subjection' (Sithole 2016b). This makes epistemic humility necessary in order to hear the unheard and pay attention to the degraded and sidelined; the need to listen intently to voices on the margins of society, even as the mainstream demand of us to also refer to its leftist voices and moderates. These are deeply ethical questions that confront those who endeavour to think through the decolonial turn.

We therefore do not choose method against method for convenience or at mere will, but it arises out of the necessity created by struggles for epistemic justice this author is committed. I therefore endeavour to write and speak from the perspective of those for whom the progress of modernity has brought much pain, injustice and scandals. I identify with the struggles of those who have been excluded, suppressed, denigrated, scorned, silenced, muted, suffocated, exploited, killed, cursed and duped in the process of establishing modernity as the superior way of living, managing power, arranging statehood, knowing, worshiping and so forth. I therefore consciously speak from the dark underbelly of a system whose friends have extolled as a civilisation and a success when in fact also a barbarity. I identify with the Biblical notion of a voice in the wilderness, a peripheral people, buried voices and a damned people. I speak not out of cold, objective 'rational' choice of topics that make sense to the academy nor inn pursuit of subjects that are new niches for those who want to stand out today. But I speak because someone has got to convey the messages of the voices of those who live, work, study and think from the valley of the shadow of death. This is not to preach to anyone, but it is to speak authentically from a position just declared rather than taken for granted Eurocentrism's illusion of a zero-point of enunciation or the scientific position that is a façade.

The ability of Eurocentrism to police thoughts of others, decide who is rational and not, who is publishable or not, whose work can be passed or failed, is one of the worst forms of injustice. It lends credence to this idea that mainstream knowledge is a form of imperialism whose aim is to impose maintain this Eurocentric monoculture of scientism. This means while we wish to choose to rebel against Eurocentric illusions and negations (including the idea that disciplines have white fathers only or that IR began in Europe and that Europeans are emboldened to declare its beginnings and end, etc.), there are terrible consequences that the centre is able to impose on us as a result. These include being kept out of the publishing platforms, academic jobs; being cut off crucial network; and being labelled as outcast, the epitome of bad academic standards. But if we don't rebel and shout let me breathe, we still suffer the suffocation. There is therefore no real choice, but to try to live, which is to combat in order to survive. This is a real experience of black colleagues in academia across the country and the world today. All these pertain to IR as a discipline as well. 
IR strives to pass the master of Eurocentric monoculture of scientific knowledge. The rebellious thoughts are required to meet the conventions of Eurocentric rationality and science, a particular tradition of science. The thinkers of the south are expected to sound like, write like and speak to the world through the language and conventions of the north. There is a significant evidence of attempts to challenge this mainstream, from Marxists to Feminists, post-colonial and subaltern thinkers, but realism-idealism family of thought remain firmly dominant without occasional acknowledgement of the other. The other's thought remains the other thoughts. Thus, we suggest that methodological considerations are not incidental to the academic entreprise generally and the decolonial turn in IR in particular. Crucial for this turn is the understanding of the method as a tool used to muzzle, to exclude, to denigrate, to silence, suffocate others and the potential to use method as a form of combat with malestream, as a tool for liberating thought. There are hugely important methodological medications required as the first step in exploring the decolonisation of knowledge and IR as a discipline. This article is framed by epistemic rebellion, a demand to think as an 'other' in IR and related fields of study. It identifies other attempts to rebel involving such figures as Dipesh Chakrabarty, Susan Strange, Ann Tickner, Spike Petersen, Cynthia Enloe, Laura Neack, Ali Mazrui, Samir Amin and Partha Chatterjee. In spite of their huge contributions, the discipline remains a discipline of Northern thinkers and their publications, a home for family feuds called theoretical debates and home for experiences of the North or in the North rather than a product of experiences from everywhere.

\section{Acknowledge coloniality in IR}

Besides unthinking methodology and positionality in IR, this article also proposes, as a second strategy towards a decolonial turn, the unmasking of coloniality at the heart of epistemological making of IR as a discipline. This entails looking closely at who speaks and who does not speak in its definitive discourses. It is to look at which civilisations, cultures and regions of the world are privileged to have a prominent or dominant position among the voices that speak on behalf of the discipline. It is not hard to find evidence to support the suggestion that IR as a discipline is dominated and controlled by men from Western Europe and other parts of the European diaspora, mainly North America and Oceania, commonly known as the global North. The fathers of the disciplines and their disciples come from the global North. From this vantage point, IR is thought to have its true genesis in the observations of Thucydides in History of Peloponnesian War, Thomas Hobbes in Leviathan and Niccolo Machiavelli in The Prince. It evolved through the development of its key schools of thought that have white men as fathers. The fathers of realism, include E.H. Carr, Hans Morgenthau and John Mearsheimer; fathers of idealism include Immanuel Kant and recently J.M. Headley; fathers of neoliberalism include Robert Keohane and Joseph Nye; fathers of constructivism like Alexander Wedt to Ted Hopf; and fathers of the English School include Headley Bull and Barry Buzan. There are no mothers and sisters in a discipline born out of imperialist patriarchal world system. There are non-white fathers and brotherhoods at the heart of the discipline. It is a conversation of men from a small region of the world, a region that acquired its privileged imperial position in world affairs through processes that include imperialism, slavery and colonialism. Though almost 100 years now as a recognisable discipline, yet 
the voices of women and non-Europeans remain faint and rare. As indicated, the hugely important attempts to bring into the equation something akin to ecologies of knowledge based on experiences outside the centre of the world system have been overshadowed by the monotony of the realism-idealism-constructivism-Marxism conversations, all fundamentally born of Western civilisation and its sciences. Some like Marxism have been useful in helping challenge the mainstream, but they too are framed and constructed fundamentally from within the Eurocentric epistemic world. This does not discount efforts by others to de-Eurocentrise Marxism, for instance, but to speak in terms of what epistemology holds sway in both right and leftist fronts of the discipline.

The mainstream literature too easily narrates the history of the discipline as a European history, from ancient Greece to the United States of America. The European experience, norms, values and rationality are therefore foregrounded as foundational to the discipline at the expense of the truth of a more diverse evolution of IR practice and thought. This is in spite of scholars like Jack Goody showing that the modern Eurocentric history of the world is a take-over of a history made of a variety of continents and civilisations by conceptualising and presenting the past as being what happened in Europe, imposing it upon the rest of the world, and thus forcing others to understand the world including where they live through Europe (Goody 2006). There is reluctance and downright resistance to hear the other (Said 1979). The discipline continues to muzzle the voices outside the global North while perpetuating the dominance of male voices from the North, their theories, their illusions and their impressions of the world including the world outside the North. The realists, idealists, liberal, constructivist, Marxist and post-modernist theories in IR are fundamentally Western voices framed by Europe's usurping of world history, even when mimicked and replicated by thinkers from the South. They remain founded on the Western experience, its philosophical iterations and cultural underpinnings. There is no major problem with Europe telling its history and celebrating its story, but the problem arises because the Western canon claims universal nature and application. It is not that it is Western that is a problem, but that it is Eurocentric in the sense Jack Goody means by the theft of history. It is that it claims to be universal that generates epistemicides and other forms of displacement of other voices and ways of knowing. The universalist claims lead to epistemicides in that in order for it to thrive as 'the knowledge' other epistemologies have to die.

Therefore, mainstream IR masquerades as international when in fact it is regional and sectional. It pretends to be about everyone, when it is an ethnocentric view of the international, a Eurocentric construction of the international. Idealism, realism, constructivism, structuralism and post-structuralism are theoretical options born in the centre of global imperialism, and this has implications for the fight for epistemic and cognitive justice. It is not by accident that these men come from the region of the world that was also behind other forms of imperialism (political, economic, cultural, environmental, etc.). It is no wonder that the mettle has since been inherited by current white men mainly, and black people of anywhere remain a very minute part of this.

\section{Texts and the voices: decolonise the IR's archive}

The third epistemic strategy in pursuit of the decolonial turn in IR is to grapple with the archive upon which the discipline is built and sustained. The classical writings that form 
the basis of the discipline, drawn in part from Europe's 'world history', are of Mediterranean Europe. What was written in ancient Greece, Italy and then modern western Europe form the essential archive of the discipline. Assessed closely, the bulk of the material that justified the existence of the IR discipline was produced in and for Europe and its diaspora in North America in the main (Wight 1966). This trend continues to this day, as almost all major pieces of IR literature are meditations of Western men in the main, sold to the whole world as universal texts. Evan Luard's magisterial work that identifies basic texts in IR confirms this enthnocentric archive on which the discipline is based (Luard 1992).

The history that underpins IR assumes 1648 and the birth of the idea of national sovereignty as a sort of a major break between a world (Europe) under feudal/religious authority and a secular modern world of nation states. This then evolves through the American and French Revolutions in the eighteenth century in which a few key IR's basic texts including John Locke's Two Treatises on Government were written. This story extends to the achievement of relative peace and emergence of balance of power in Europe in the nineteenth century after the 1815 defeat of Napoleon Bonaparte. To the twentieth century belongs the rise of nationalism after the call of the Ottoman, Russian and Austria-Hungarian empire, the rise of a liberal world order with the League of Nations and later the United Nations emerging as central institutional scaffolds for this new order. This history culminates in the Cold War, what we regard as a family feud within Western civilisation, a contest between Western ideas and ideologies - liberalism and communism - into which we the peoples outside the West were drawn (Mingst and Arreguin-Toft 2010). The end of the Cold War is assumed to be the 'end of history', the exhaustion of ideological contestations, the dissipation of competition challenging the Western civilisation, the victory of the Western idea (Fukuyama 1989). This echoes the assumptions about end of ideology in the 1960s (Bell 1960). In line with this history, European thinkers have begun to see both the decline of IR and the end of IR today (EJIR 2013).

Therefore, the history and memory on which students of the world including African students are meant to remember their place in the world are those of the region of the world that recently dismembered, denigrated, underdeveloped and oppressed Africa and other continents in the first place. The history that is taken for granted is that of the oppressor, giving very little attention to the suffering of the oppressed and very little credit to the agency of the once colonised. The denigrated are to epistemically travel to Europe in order to understand the foreign policies, diplomatic practices, negotiation practices and international roles of their countries and region. This is the very nature of the coloniality of knowledge, as explained by Ramon Grosfoguel in 'Decolonial Approach to Political-Economy', where he said: 'Precisely, the success of the modern/colonial world-system consists in making subjects that are socially located on the oppressed side of the colonial difference, think epistemically like the ones in the dominant positions' $(2009,13)$ On the operations of this type of epistemic injustice embedded in universalist discourses pretending to be cosmopolitan, Mafeje $(2011,36)$ suggests the following: 'Before they have rediscovered themselves and have exorboured (sic) on the continent for so long, African scholars are being invited to an extraverted contemplation about "our common future."' The Eurocentric designs are invested in creating an illusion that the discipline and its claims are universal in the sense that they represent everyone; it is to constantly claim that IR is really international relations of everyone when in fact it is 
IR of European tradition, a European gaze on the world and a Eurocentric construction of the international.

The conversations are about globally common challenges and shared aspirations before there has been a reparation of historical injustice in the construction of the discipline and the practice of IR. Questions about whose construction of the international, whose constitution of global power, whose values and norms, whose notion of political economy, whose international society, whose history and story are included are not being raised as sharply as Eurocentric concerns about world orders, international security, the responsibility of world powers, the obligations of middle and emerging powers, and forth.

Fundamental to the decolonial turn therefore is to call into question the assumptions that the text and archive are ours when in fact they are someone else's. It is to unmask the illusion of a text for all when the text is the story of a province of the world and its diaspora. This is evident in the main textbooks used to teach IR; they are generally Eurocentrically conceived, epistemologically Eurocentric, ontologically European/North American and about world views from this province of the world. Of course, many now include this or that, in the form of examples, textboxes and case studies from outside the European world, but this too is undergirded by Eurocentric epistemology, what Portugal's academic, Boaventura de Sousa Santos quoted above calls the monoculture of scientific knowledge which is Eurocentric.

It also means fighting for the presence of the marginalised in the remaking of the centre of the knowledge production and dissemination of the texts born of the literature and orature of other civilisations and provinces of the world. This is not just about addition of the other at the end of the list as a sort of an affirmative action, but it is about rethinking the world, the international, the themes, the key questions, the actions on the basis of reading/listening effectively to voices outside Eurocentrism, thus making the archive practically international rather than internationalised. On this basis, the golden thread of IR as an area of discourse must represent a dialogue and debate beyond Eurocentrism, not Eurocentrism plus others. The burning of libraries and the burning of books/texts that happened as coloniality expanded out of Europe into other continents was a high mark of epistemicide and justice means bringing to life the knowledges about the world that were burned and banned, denigrated and ignored. Decolonise must mean reversing the injustice of colonising in the first place and in respect of the texts and voices that speak in IR, we will need to allow voices of Africa, Asia and other ignored areas from time immemorial to fairly compete in defining what is international, what is IR and how does it function.

There are two levels clearly open to us today in undoing the coloniality of the archive on which IR is based. The first is what Santos called granting 'equality of opportunities' to different kinds of texts, from different kinds of knowledge to engage in ever wider epistemological debates within IR to help democratise knowledge. We have referred earlier to a large list of dissenting voices that have sought to think from outside the mainstream and to give voice to the south, which we argue need to be brought back to the centre of the discourse, to help shape the very structure of the discipline and pose new questions about the international rather than being added to the Eurocentric framework of the discipline. They need to be foregrounded and treated fairly as texts and voices. This is about bringing texts recently produced back to the centre in the reconstitution of the archive as 
equals in the conversation of texts and epistemologies. It is also about re-discovering those texts that have been allowed to disappear, the ancient texts about the world that were excluded as inconvenient to the Eurocentric usurpation of world history by European history imposed on the world as world history. It is about the excavation of buried and burned texts and voices. In this, we go beyond the written text, because written bestows unjustly higher value on some texts over others on the basis of Eurocentric scientific assumptions about what is authentic, quality and reliable. To this discussion of standards and conventions, we must ask: whose? And why?

\section{Pedagogy of coloniality: liberating the IR classroom}

The fourth entry point in shifting the geography of reason in IR is that about the fundamental transformation of pedagogy. The liberation of the teaching practice in class begins with the liberation of the teacher in class and therefore the taught, helping to end the dichotomy of teacher-learner that imposes a hierarchy in place of horizontal conversation among human beings in class. The class also seizes to be a four-walls setting organised in the hierarchy of teacher in front and classes in the auditorium whose due is to listen (auditorium) to one who lectures. It ceases to move from the premise that the teacher/lecturer knows (on the basis of texts from European world) and the students does not know. It also no longer becomes the transfer of the text from the centre to the students from the periphery, this huge dependence on the prescribed and recommended textbook.

In Pedagogy of the Freedom, Freire $(1998,93)$ outlines the moral-ethical moment we confront as teachers as follows:

I cannot be a teacher if I do not perceive with even greater clarity that my practice demands of me a definition of where I stand. A break with what is not right ethically. I must choose between one thing and another thing.

What stand we then take when teaching IR as a discipline and when discussing with students what constitutes international questions of note? What ethical position do we take in relation to the Eurocentric texts that constitute the main teaching literature? What ethically speaking is our position in relation to the colonial foundations of the discipline and its interpretation of areas of encounter and tension between the hegemonic civilisation and others? How do we teach IR, world history, and foreign policy: do we teach to pass Eurocentric illusions and negations on to students or do we unmask the moral questions that hang over the discipline and its claims, and teach students to question?

This matter of choice is made necessary by the prior moral questions inherent in the constitution of social science as a form of imperialism. It is a complex dilemma produced by the very fact that modern knowledge and its disciplines are built on morally bankrupt processes of epistemicides, cultural murder and theft of history (Grosfoguel 2013). The subalterns that enter discourses of IR in a class room situation have to decide where they stand on the implication of the discipline in epistemic racism and cognitive injustice, deeply problematic accusations that the discipline is yet to answer to convincingly. If the default position for authentic engagement of the discipline by subaltern thinkers and teachers is one of epistemic rebellion, a sort of combat, then what are the implications of this on pedagogical positioning? 
What are the ramifications of our loci of enunciation or choices about whether we want to think from the vantage point of the dominated or the dominant, for the practice of teaching in the IR field. The content we teach and rituals we demonstrate may perpetuate the injustices of Eurocentrism as a point of view. For instance, it is in class that we often indoctrinate the young ones about a fiction called Sub-Saharan Africa when actually this is a euphemism for what was once called negroid Africa, a highly racialised way of thinking about geography that major Eurocentric philosopher, Hegel, did much to entrenched. Hegel helped give credence to the idea of continents matching racial classifications, so that Africa was black, Europe black, Asia yellow and so forth. The splitting of Africa into Arab and Negroid parts is a science of Europe, born out of Europe's obsession with race and classification of its dominated parts (Tibebu 2011). Such concepts as postCold War in spite of on-going cold war or a New World Order though decolonisation and de-imperialisation of the world order happened, and a multipolar world though the same region continues to dominate the world system have been internationalised when they actually are purely Eurocentric in their origin and conceptualisation. Critical to decolonising pedagogy is to question, and distance ourselves from, technologies of domination and unfreedom such as fundamental concepts and underlying questions being responded to in the mainstream conversations, especially those born out of obnoxious colonial, imperialist, patriarchal and racist concerns.

A decolonial turn for the teaching of the discipline will lead to the questioning of the idea of teaching in rectangular spaces called class rooms, the idea of having a black board in front and podiums for the use of the teacher or others that the teacher chooses, and other uses of space that legitimise problematic notions of knowledge and power. This ubiquitous format of teaching as instruction and transfer of knowledge from the knower to the unknowing has huge implications where teachers tend to be white, older and male, and the taught are mostly black, female and young. We replicate and thus reinforce the notions of hierarchy and inherently unequal relations in society even along race, gender and socio-economic lines. This is part of what is called the hidden curriculum and it may be that this has more bearing on what is learned than what is actually said or not said during a class interaction or in study guides or textbooks. How does one teach critical rebellion against global power asymmetry, imperial designs in world affairs, war and conflict, and so forth while maintaining a classroom situation that affirms hierarchy and inequality?

\section{Disrupting the crucial IR monologue on endings and beginnings}

There are many major debates around which the discourses in IR organise themselves and these constitute a monologue that Eurocentrism has on the basis of own concerns imposed upon the world. Critical to decolonial turn is to break out of these debates both by exposing their Eurocentric nature and by actively questioning or disrupting the family debate that excludes us. What is required for this to happen is a shift in epistemic positionality both in thought and in the practice of IR in order to make possible to equality of opportunities for ecologies of knowledge rather than mimicry of debates of only one member of the international community of knowledges. The positions that different people occupy in relation to the process of constituting what is knowledge and in reproducing and disseminating it are crucial because they lead to questions of asymmetric 
power relations in the academy and the knowledge sector generally. The ability of Europeans and Eurocentrists to declare beginnings and ends is evident in at least three areas (history, ideology and theory) is to claim to occupy the position previously thought to be occupied by God, the God eye view on the world and others. It is about the ability to occupy such a position as to tower over fellow beings thereby diminishing them into things to be commanded, sub-beings to be instructed, and non-beings whose positions can be ignored. Eurocentrism gives to Western voices such audacity of self-belief (Kwarteng 2012, 493) that they start to declare unilaterally the beginning and the end of conversations and debates even before those thinking from outside Eurocentrism have added their voices. So, not only does Eurocentric IR claim a God's eye view on things, but it also inherits God's ability to declare ends and begins, alpha and omegas, thus excluding 'others' from conversations being had. We would like to focus therefore on just this one small part of the big debates, those that relate to the claim to alpha and omega role, the ability to start and end conversations even before others have entered at their own terms. I am aware that there are many other conversations that could be classified under other principles of coloniality, but time and space only permits us to illustrate with the debate on ends and beginnings.

There are three obvious and prominent theses that we wish to use to illustrate this feature of Eurocentrism in IR. The first is the declaration of end of history in the early 1990s in reference to the end of the Cold War as a victory for the West, its ways and its ideas. Even before geo-political/ideological options outside the Capitalist-Communist battle had entered the competition of ideas on how to solve the world's problems, the end was declared. Francis Fukuyama declared that the Cold War contestation of ideologies, ideas and ways of politics had ended with a victory for the West (Fukuyama 1989), thus foreclosing the possibility that the ideological positions of subalterns in Africa, Asia and the black Atlantic (Latin America and blacks in North America) might contribute ideas on how to build a better world for all. He wrote and others echoed in a manner that suggested that there was no longer an alternative to Western liberalism (most evident in liberal democracy, liberal economics and individualistic lifestyles), but only options within. The literature has gone on to speak as if democracy is the only allowed form of politics, failing which democracy can be imposed by development aid, cajole and even by military means. In this discourse, it is accepted that the capitalist option is the only one on offer, the choice is only a variety of it, from free market to statist forms. Because they believe that there has been a clash of civilisation, they also believe that how it ends is a victory for one. What Headley (2007) describes as a successful Europeanisation of the world is the hidden transcript of much of IR's 'malestream' literature (Carver 2004).

The second example is the declaration of the end of ideology, which dates back to Daniel Bell's End of Ideology, which has since been updated to take into account the end of history thesis. In this, Bell drew from similar suggestions by Albert Camus (LeviValensi 2007) and Aron (1957) essentially about their world in the 1950s and 1960s, which Bell thought had been reaffirmed. This argument was part of a monologue of voices throughout Europe and North America that suggested the exhaustion of political ideas that emerged as alternatives of Western ideas. There were differences of opinion among them about the nature, character and reasons for this end, but there was general consensus on the declaration of the end of fundamental contestations over 
ideologies. By ideology, they meant a set of political beliefs towards a utopia and revolution. Academic debates echoed in political discourses suggested that Marxism as a political ideology had reached a cul-del-sac, unable to cheat its inevitable death as a result of its failure to reconcile its absolutist logic that ends justify means with the need for ethics in modern society. While Marxism's relevance as an academic theory was recognised, its life as a political ideology (especially communism and socialism) was considered exhausted. Of course, many voices challenged these ideas, but largely not for their Eurocentric bias, but on one or another factor related to the logic of the argument.

While in much of the European debate of the 1950s, end of ideology, was death of Marxism rather than victory of capitalism, in the 1960s the likes of Stuart Hughes extended the thesis to celebrating the inevitable victory of capitalism over communism, the Western idea over other ideas including communism. Aron (1957, 309), on his part, suggested that societies had evolved such that neither pure liberalism nor versions of socialism were able to offer value beyond inspiring small groups of adherents. Unlike others, he did not see the end as a victory of one specific ideology over another, but exhaustion of pure political ideologies as a result of intermixing of aspects of main ideologies of the time. As a result, capitalist societies had socialist tendencies and vice versa. After an argument highlighting miscegenation of ideologies, Aron $(1957,325)$ concludes that it was because Europe was aware of the plurality of civilisations 'but did not doubt the universality of its message'. 'Europe', he continued,

which has finished conquering and is already succumbing to its victory and the revolt of its slaves, hesitates to admit that its ideas have conquered the universe but have not kept the form they used to have in our own debates and controversies.

He meant the end of ideology implies the universalisation of the European idea even though in its expansion the slave revolts have changed aspects of the idea. There is thus a tacit recognition of the impact of the oppressed on the Western idea as it went about conquering the world. The main focus though is that the Western idea prevailed. It is that the very contest between capitalism and communism was a battle between Western ideologies, one esteemed and another degraded (Aron 1957, 330).

'In the Western societies, the ideological controversy is dying down', says Jacoby (1999, 1) echoing one small part of Aron's argument. For the bulk of the voices, the salience of the Western idea in the end was not through miscegenation with the other's ideological revolts, but through its triumph over them. For Martin Lipset, it was the victory of the social democratic experiment in Europe. For Headley, it was the osmosis of the values and norms of Western liberalism. For Bell $(1960,293)$, it was 'the horrors of Soviet communism and success of liberal capitalism'. On went the conversations, setting the tone for Fukuyama's end of history idea, a phrase that can be traced to another of Aron's work, entitled Opium of Intellectuals, which came out five decades earlier.

Astoundingly, these Eurocentric voices also agreed that there was now broad consensus punctuated by disagreements that were no longer fundamental. There no longer were fundamental differences on ideological lines, meaning within the province of the world from which they speak. There were no deep differences on critical political issues like the state and its role, its relations with citizens, political processes and procedures, notions of power, demands of leadership, citizenship and so forth. Headley (2007) extends this to what is assumed to be general consensus across the world today on the 
universal value of liberal democracy, human rights and private property. It is the most widespread subliminal message of malestream IR that the Western liberal idea has prevailed, what is remains to happen is its full implementation, consolidation, diversification in various forms and its procedures (Whitehead 2001; Schraeder 2003; Newman and Rich 2004; Elkink 2011).

The third thesis consolidated in a special edition of the European Journal of International Relations in 2013 was whether IR theory had come to an end. In this edition, European thinkers reflected on the phases of the development of IR theory the 1960s. They identified four major theoretical traditions that largely borrowed from political science proper: realist, idealist/liberal, Marxist/structuralist and constructivist traditions. They also identified and deliberated on three key drivers of proliferation of IR theory. First is the invention of new theories as scholars contended with new historical contexts and changing dynamics in the international environment that necessitated new conceptual tools of analysis. The second driver identified is the practice of importing theory from cognate disciplines like international sociology (constructivism) and philosophy and literary studies (post-structuralism). Third is developments within the discipline itself such as the publication of works that presented IR in terms shaped strongly by particular theoretical lenses such as Kenneth Waltz's Theory of International Politics in 1979 that instigated the search for and the presentation of alternative theoretical positions.

The discourse also reflects broadly on the state of malestream IR theory and the growing role of critical theory with its intention to open IR theory up to a plurality of perspectives. It includes revisiting the debates of the 1990s and 2000s revolve informed by the scepticism about the efficacy of critical theory and emerging alternative theory. As the special edition shows, this scepticism is epitomised by Robert Keohane's warning that to be taken seriously these emerging theories needed to adopt 'rationalistic' premises of malestream theoretical discourses or remain on the margins. There are also views that are in favour of the proliferation of new theories, anticipating a greater impact of critical theories, yet they still largely see this in the frame of critical theory, by which is meant largely Marxist and therefore European theories (Dunne, Hansen, and Wight 2013). While the view in favour pluralism accepts the idea of diversity in IR theory as a necessity, they are yet to see this as including ways of knowing and lenses developed outside of, and in rebellion to, Eurocentrism (Smith 2003). This is not to say they oppose or stand against this emergence from outside the geo-political epistemic centre, but that they seem ignorant of the existence of theoretical debates on these margins of Westernised and Westerndominated scholarship.

The history and evolution of IR theory has generally been told in terms of epic battles or great debates among predominantly Western thinkers and actors as well as from the perspective of Western voices (Lake 2013). The Western discussion referred above assumed that all the key debates have been concluded. There is general consensus first that there are these grand debates that mark out key moments in the evolution of IR and its theory, and that there are three or four of them. The first is said to have raged just after the Second World War between idealists who dominated from the break of the twentieth century and realists that gained ascendancy after the war. The contest was heavily influenced by the need to prevent the recurrence of war with the former pinning their hope on the role of institutions in improving human conditions, an ideal that was dealt a big blow by the failure of institutions to prevent the outbreak of the Second World War. This gave 
prominence to realists' claim to understand human nature and the world as they are rather than as they ought to be, focusing on inherent conflict, competition and anarchy.

The second debate is said to have taken place from the 1960s, which took the form of a battle between so-called traditionalists and scientists. The former argued that the world and its politics were too complex for any scientific theory to interpret with précising and that each historical juncture is unique, whereas scientists/behaviourists believed in the ability of scientific theory to identify commonalities among historical events as the basis for generalisations by induction or deduction.

The third grand debate pitted realism and liberalism against radicalism in the 1970s. This arose partly because of the rise of radicalism to challenge the orthodoxy that saw as a shared feature of both idealism and liberalism. They saw both as advancing ideas meant to main rather than rethink, dethrone, transform or destabilise the status quo. Radical theorists were those who saw the distinction between realism and idealism as superficial, and therefore argued for a third way, one for a radical transformation of the capitalist liberal order.

The fourth and last is thought to be the debate that emerged in the 1980s between neoliberalism, neorealism and constructivism. Sometimes, this is reflected as a debate between positivists/rationalists who had strong faith in social science as a method and reflectivists that included constructivists, critical theory, post-modernists and feminists joined together by the idea of openness of various taken-for-granted aspects of world politics. The positivists were a more unified side than was the reflectivists that was a divergent group of theorists, joined together by their intention to take on the mainstream IR theoretical positions (Weaver 1996).

Of course, in this narrative, the host of voices speaking from outside the Western canon are almost non-existent and absent except as echoes. These voices have been speaking for ages and texts have increased, but the mainstream is aware of the implications of opening equal opportunities for these 'other' ways of thinking for its ability to dominate and masquerade as international. The imperialism of the discipline and its debates implies that it seems that we have witnessed contestations only within the Western monologue. It is as if perspectives challenging the Western canon as a whole as inadequate at least and as a deeply problematic example of epistemic injustice have not said anything significant to affect the evolution of the discipline. Voices arising from Latin American revolutionary and radical thought, Asian subaltern thought, African epistemic rebellions are also subsumed under an unclear category of post-structuralists or radicals or critical theory that is hardly discussed seriously.

\section{Conclusion}

The decision to close the debate on IR theory, the declaration of the end of IR theory, epitomises what is deeply unjust about the constitution of IR as a discipline and its theory. This like the discourses on ends of history and ideology exemplifies the imperialism of IR as a case of coloniality of knowledge whose implication is to exclude, denigrate, neglect, ignore, subordinate and destroy fundamental diversity of ways of knowing. This justifies the call for decolonisation of knowledge generally and IR in particular, which is to go beyond the diversity of voices within Eurocentric IR, but asks us to contemplate de-centring the Eurocentric story in order to make possible true epistemic pluriversality. This 
article sought to offer from a decolonial epistemic lens a perspective on unmasking epistemic injustice in IR theory, suggesting where we might start in decolonising IR and its theory. It suggests what might be the basis for shifting the geography of reason in order to enable diversification, decolonisation, de-imperialisation and Africanisation of IR. Five critical epistemic strategies are suggested as fundamental to achieving the decolonial turn in the discipline. It does not go into what exactly then follows as part of the actual process of creating equal opportunities for other knowledges, what forms would these take, because this is a completely different subject that must be explored in subsequent publications.

\section{Disclosure statement}

No potential conflict of interest was reported by the author.

\section{References}

Ake, C. 1979. Social Science as Imperialism: The Theory of Political Development. Lagos: Ibadan University Press.

Aron, Raymond. 1957. The Opium of Intellectuals. New York: W\&W Norton Company.

Bell, Daniel. 1960. The End of Ideology: On the Exhaustion of Political Ideas in the Fifties. Cambridge, MA: Harvard University Press.

Blaut, J. M. 1993. The Colonizer's Model of the World: Geographical and Eurocentric History. New York: The Guilford Press.

Carver, L. 2004. Men in Political Theory. Manchester: Manchester University Press.

Chabal, Patrick. 2012. The End of Conceit: Western Rationality after Postcolonialism. London: Zed Books.

Dunne, T., L. Hansen, and C. Wight. 2013. "The End of International Relations Theory?" European Journal of International Relations 19 (3): 405-425.

EJIR (European Journal of International Relations). 2013. "Special Edition, 2013 - End of International Relations Theory."

Elkink, Johan A. 2011. "The International Diffusion of Democracy." Comparative Political Studies 44 (12): 1651-1674.

Filho, Joao, and John Collins. 1998. "Students and Politics in Brazil, 1962-1992." Latin American Perspectives 25 (1): 23-37.

Freire, Paulo. 1998. Pedagogy of Freedom: Ethics, Democracy and Civic Courage. Translated by P. Clarke. Lanham: Rowman and Littlefield.

Fukuyama, F. 1989. "End of History?" National Interest, Summer edition, 1-8.

Goody, Jack. 2006. The Theft of History. Cambridge: Cambridge University Press.

Gordon, Lewis R. 2010. "Theory in Black: Teleological Suspensions in Philosophy of Culture." Qui Parle 18 (2): 193-214.

Grosfoguel, Ramon. 2009. "A Decolonial Approach to Political-Economy: Transmodernity, Border Thinking and Global Coloniality." Kult- Special Issue: Epistemological Transformation Fall: 10-37.

Grosfoguel, R. 2013. "The Structure of Knowledge in Westernized Universities: Espistemic Racism/ Sexism and the Genocides/Epistemicides of the Long $16^{\text {th }}$ Century." Human Architecture 11 (1): 73-90.

Headley, J. M. 2007. The Europeanisation of the World: On the Origins of Human Rights and Democracy. Princeton, NJ: Princeton University Press. 
Jacoby, R. 1999. End of Utopia: Politics and Culture in the Age of Apathy. New York: Basic Books.

Kwarteng, Kwasi. 2012. Ghosts of Empire. London: Bloomsbury.

Lake, David. 2013. "Theory is Dead, Long Live Theory: The End of the Great Debates and the Rise of Eclecticism in International Relations." European Journal of International Relations 19 (3): 567-587. Levi-Valensi, J. 2007. Camus at Combat Writing 1944-47. Princeton, NJ: Princeton University Press.

Luard, Evan. 1992. Basic Texts in International Relations: The Evolution of Ideas about International Society. New York: St. Martin's Press.

Mafeje, Archie. 2011. "A Combative Ontology." In Postcolonial Turn: Imagining Anthropology and Africa, edited by Raul Devisch, and F. B. Nyamnjoh, 31-41. Bamenda: Langaa.

Maldonado-Torres, N. 2011. "Thinking Through the Decolonial Turn: Post-Continental Interventions in Theory, Philosophy and Critique - An Introduction." Transmodernity: Journal of Peripheral Cultural Production of the Luso-Hispanic World 1 (2): 1-16.

Mignolo, W. 2009. "Epistemic Disobedience, Independent Thought and Decolonial Freedom." Theory, Culture and Society 26 (7-8): 159-181.

Mignolo, W. D. 2011. "Epistemic Disobedience and the Decolonial Option: A Manifesto." Transmodernity 1 (2): 44-66.

Mingst, K. A., and I. M. Arreguin-Toft. 2010. Essentials of International Relations. New York: W.W. Norton \& Company.

Naicker, C. 2016. "From Marikana to \#feesmustfall: The Praxis of Popular Politics in South Africa." Urbanisation 1 (1): 53-53.

Newman, Edward, and Roland Rich, eds. 2004. The UN Role in Promoting Democracy Between Ideals and Reality. Tokyo: United Nations University Press.

Santos, B. S., J. A. Nunes, and M. P. Meneses. undated. "Opening Up the Canon of Knowledge and Recognition of Difference." Accessed August 12, 2017. http://www.boaventuradesousasantos.pt/ media/Introduction(3).pdf.

Schraeder, Peter J. 2003. "The State of the Art in International Democracy Promotion: Results of a Joint European-North American Research Network." Democratization 10 (2): 21-44.

Sithole, T. 2016a. "Researching the African Subject in African Politics." In Decolonizing the University, Its Knowledge and Disciplines, edited by Sabelo J. Ndlovu-Gatsheni, and S. Zondi, 213-234. Durham: Caroline Press.

Sithole, T. 2016b. Steve Biko: Decolonial Meditations of Black Consciousness. London: Lexington Books. Smith, S. 2003. "Dialogue and Reinforcement of Orthodoxy in International Relations Theory." International Studies Review. 48: 499-515.

Tibebu, T. 2011. Hegel and the Third World: The Making of Eurocentrism in World History. New York: Syracuse University Press.

Venter, R. 2015. “\#FeesMustFall and the SA Economy." Focal Point 2015. Accessed August 12, 2017. https://www.newsclip.co.za/Uploads/Files/feesmustfall.pdf.

Waltz, K. N. 1979. Theory of International Politics. Reading: Addison-Wesley.

Wa Thiong'o, N. 1986. Decolonising the Mind. Portsmouth: Heinemann Educational Books.

Weaver, O. 1996. "The Rise and Fall of Inter-Paradigm Debate." In International Theory: Positivism and Beyond, edited by S. Smith, K. Booth, and M. Zalweski, 149-185. New York: Cambridge University Press.

Whitehead, Laurence, ed. 2001. The International Dimension of Democratization: Europe and the Americas. Oxford: Oxford University Press.

Wight, M. 1966. "Why is There No International Theory?" In Diplomatic Investigations, edited by M. Wight, and H. Butterfield, 16-33. Cambridge, MA: Harvard University Press.

Williams, J. 2015. "Remaking Education from Below: The Chilean Student Movement as Public Pedagogy." Australian Journal of Adult Learning 55 (3): 496-514.

Zeleza, P. T. 2006. "Introduction: The Internationalisation of African Knowledges." In The Study of Africa: Disciplinary and Interdisciplinary Encounters, edited by Paul Tiyambe Zeleza, 1-24. Dakar: CODESRIA Books. 